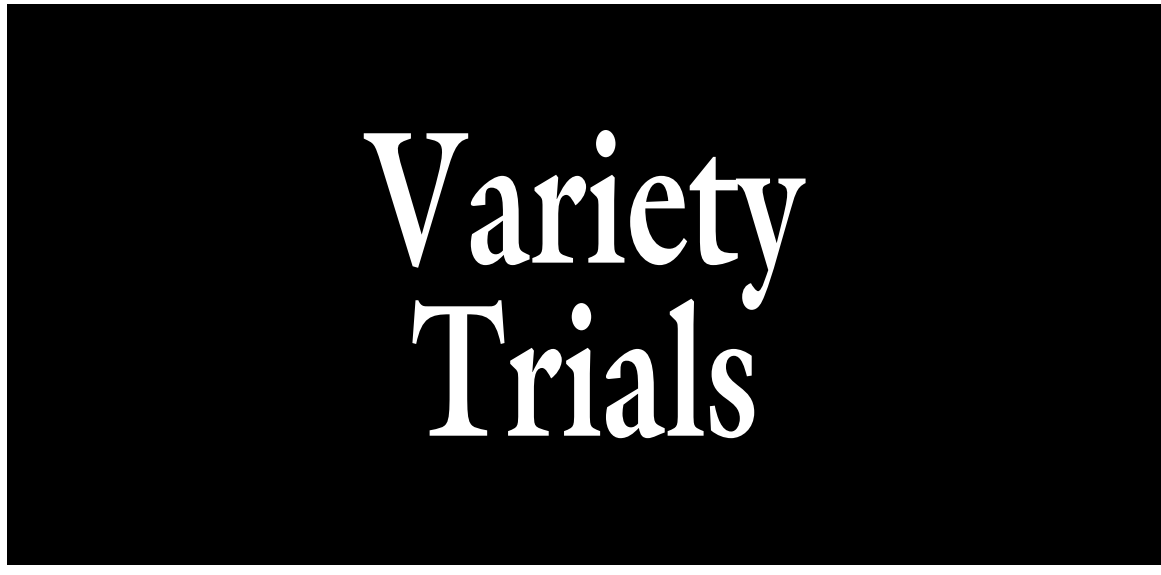

\title{
Performance of Alternative European Wine Grape Cultivars in Southwestern Idaho: Cold Hardiness, Berry Maturity, and Yield
}

\author{
Krista Shellie ${ }^{1,3}, J$ acob Cragin ${ }^{2}$, and Marcelo Serpe ${ }^{2}$
}

ADDITIONAL INDEX WORDS. differential thermal analysis, low temperature exotherm, phenology, viticulture, Vitis vinifera

Summary. The cold tolerance, phenology, yield, and fruit maturity of alternative red- and white-skinned wine grape cultivars (Vitis vinifera) of European origin were compared with those of 'Merlot' and 'Cabernet Sauvignon' over two growing seasons in southwestern Idaho. Variability among alternative cultivars was detected for cold hardiness, onset of phenological events, yield, and fruit composition. The red-skinned cultivars Montepulciano and Tinto Cão were the least cold hardy of the alternative cultivars. The red-skinned cultivars Aleatico, Aglianico, and Graciano had similar yield but matured later than the leading cultivars Merlot and Cabernet Sauvignon and were among the more cold-sensitive alternative cultivars. 'Grüner Veltliner', 'Sauvignon Gris', and 'Trousseau' cold acclimated early, had high midwinter bud cold hardiness, and had similar or higher yield and fruit maturity as the leading cultivars. The white-skinned cultivars Verdelho, Fernão Pires, Sauvignon Blanc Musqué, and Sauvignon Gris had similar or less vine injury, similar or earlier phenology, and similar yield and fruit maturity as the leading cultivars. The large berry size of the red-skinned cultivars Trousseau and Touriga Brasiliera warrants evaluation for wine quality. The cultivar variability identified in this study for cold hardiness, phenology, cluster architecture, and yield provides a useful guide for cultivar site selection.

$\mathrm{W}$ ine grapes have high economic value because of their combined farm gate price, associated agribusiness revenue, and attraction to tourists. Retail wine in the United States has an estimated value of $\approx \$ 30$ billion and the state of California accounts for $\approx 90 \%$ of domestic wine production (U.S. Department of Commerce, 2011). The high economic potential of the wine industry has stimulated the expansion of wine grape acreage into climatic regions previously considered unsuitable for commercial production. Grape acreage in Idaho is second only to apple (Malus $\times$ domestica) in percentage of total fruit acreage and it increased by $86 \%$ from 1999 to 2007 [U.S. Department of Agriculture (USDA), 2007]. Winery revenue in Idaho increased from $\$ 15$ to 52 million from 2002 to 2008 (Bierle et al., 2008; Foltz et al., 2007). The estimated economic impact of the Idaho wine grape industry to the state of Idaho in 2008 was $\$ 73$ million (Bierle et al., 2008).

The majority of vineyards in Idaho are located in the western Snake River Plain at elevations between 2280 and $2919 \mathrm{ft}$ (Gillerman et al., 2006; Jones et al., 2010). Cold is a major factor that limits wine grape production in this region. Annual cold events in the spring and fall delimit the length of the growing season. Seasonal differences in growing season duration influence the ability of the vine to ripen fruit to maturity and to cold acclimate in the fall. Bud viability and vine vigor in the upcoming growing season are influenced by tolerance to midwinter cold and warming events as well as cold events that occur during deacclimation in the spring. Despite limitations imposed by cold temperature, other climatic features, such as the Mediterranean type pattern of precipitation, readily available supply of water for irrigation, high incidence of cloudless days, and high solar radiation offer major advantages for growing wine grapes in this region. The low humidity and high elevation of this region creates large diurnal temperature differences that facilitates fruit maturity by conserving respiratory substrates in the vine and berry. Cultivars of wine grape suitable for production in the western Snake River Plain of Idaho must be able to produce and ripen fruit at a commercially competitive quantity and quality during growing seasons of variable length and to survive exposure to winter cold.

Despite the large heterogeneity available among cultivars of wine grape, global wine grape production remains dominated by a few leading cultivars of European origin, with 'Cabernet Sauvignon' and 'Merlot' being the most widely planted redskinned cultivars and 'Thompson Seedless' and 'Airen' being the most widely planted white-skinned cultivars (Fegan, 2003). Many leading whiteand red-skinned wine grape cultivars

\begin{tabular}{llll}
\hline $\begin{array}{l}\text { Units } \\
\text { To convert U.S. to SI, } \\
\text { multiply by }\end{array}$ & U.S. unit & SI unit & $\begin{array}{l}\text { To convert SI to U.S., } \\
\text { multiply by }\end{array}$ \\
\hline 10 & $\%$ & $\mathrm{~g} \cdot \mathrm{L}^{-1}$ & 0.1 \\
0.3048 & $\mathrm{ft}$ & $\mathrm{m}$ & 3.2808 \\
2.54 & inch $(\mathrm{es})$ & $\mathrm{cm}$ & 0.3937 \\
0.4536 & $\mathrm{lb}$ & $\mathrm{kg}$ & 2.2046 \\
$\left({ }^{\circ} \mathrm{F}-32\right) \div 1.8$ & ${ }^{\circ} \mathrm{F}$ & ${ }^{\circ} \mathrm{C}$ & $\left({ }^{\circ} \mathrm{C} \times 1.8\right)+32$
\end{tabular}


have been found to produce commercially acceptable quantities of highquality fruit with sustainable tolerance to cold (Fallahi et al., 2004; Shellie, 2007). The leading red-skinned cultivars Cabernet Sauvignon and Merlot comprise about a third of the commercial producing acreage in Idaho with the white-skinned cultivars Riesling, Chardonnay, and Gewürztraminer making up the rest (Gillerman et al., 2006). Fruit produced in Idaho must compete for winery contracts against fruit grown in more established, well-known production regions. Wine grape cultivars of European origin, not currently being grown commercially in well-established, competing production regions, may offer an economic alternative for growers in nontraditional growing regions. However, little information is available about how these alternative cultivars perform in regions where the growing season is delimited by winter cold.

The objective of this study was to evaluate the viticulture performance of some alternative wine grape cultivars under the growing conditions of southwestern Idaho and compare their yield, fruit maturity, and cold tolerance to that of leading cultivars already in commercial production in this region. A field trial was established in a commercial vineyard in southwestern Idaho where the performance of 'Cabernet Sauvignon' and 'Merlot' was compared with wine grape cultivars from production regions in Portugal, Spain, Italy, Austria, Chile, and France. The practical goal of this research was to identify novel

\footnotetext{
Funding for this research was acquired through grant monies from the Viticulture Consortium West, the Idaho State Department of Agriculture Specialty Crop Block Grant Program, and Agricultural Research Service project 5358-21000-034-00D entitled "Production Systems to Promote Yield and Quality of Grapes in the Pacific Northwest." The trial was established in coordination with the NE-1020 project entitled "Multi-state Evaluation of Winegrape Cultivars and Clones." We thank Alan Muir, Monte Shields, and Cheryl Franklin-Miller for their technical expertise and Winemakers LLC for the use of their field resources and materials. Mention of a trademark, proprietary product, or vendor does not constitute a guarantee or warranty of the product by the U.S. Dept. of Agriculture and does not imply its approva to the exclusion of other products or vendors that also may be suitable.

${ }^{1}$ U.S. Department of Agriculture, Agricultural Research Service, Horticultural Crops Research Unit, Worksite Parma ID, 29603 U of I Lane Parma, ID 83660

${ }^{2}$ Department of Biological Sciences, Boise State University, 1910 University Drive, Boise, ID 83725

${ }^{3}$ Corresponding author. E-mail: Krista.Shellie@ars.usda.
} gov. planting material with potential to enhance the competitiveness of wine grape production in less traditional production regions with climatic conditions similar to southwestern Idaho.

\section{Materials and methods}

The trial was established in 2008 at a site in a commercial vineyard in Nampa, ID (lat. $43^{\circ} 28^{\prime} \mathrm{N}$, long. $116^{\circ} 40^{\prime} \mathrm{W}$, elevation $\left.2760 \mathrm{ft}\right)$. The climate in this area has a Koeppen classification of BSk (cold, semiarid, steppe) with an average annual precipitation of 9 inches (U.S. Department of the Interior, 2013). Based on survey data, the soil at the site is a silt loam, Scism series, Haploxerollic Durorthids (USDA, 1972, 2013). Soil samples collected by Terra Spāse (St. Helena, CA) in 1999 and analyzed by A \& L Western Agricultural Laboratories (Modesto, CA) reported a $\mathrm{pH}$ of 8.1 (measured as saturated paste) and $1.8 \%$ organic matter in the top 24 inches of soil (determined by dry combustion). Growing-degree day (GDD) heat unit accumulation was calculated for each year of the study using weather data recorded at the Agrimet weather station located in Nampa, ID (U.S. Department of the Interior, 2013). Accumulated GDD was calculated from the simple average of daily maximum and minimum temperatures using a base temperature of $10{ }^{\circ} \mathrm{C}$ with no upper temperature limit.

The experimental design of the trial site was a randomized block with cultivars planted in four-vine panels in six blocks. Rows were oriented northto-south with $8 \mathrm{ft}$ between rows and 6 $\mathrm{ft}$ between vines. The perimeter of the trial was planted with a single row of vines that served as a border. Vines were grown with double trunks, and each trunk was trained to form a unilateral cordon arm that was $\approx 3 \mathrm{ft}$ long and located $\approx 3 \mathrm{ft}$ above the soil surface. Each cordon arm was dormant pruned annually to retain seven spur positions with two buds per spur. The shoots were vertically positioned during the growing season and held in place with two movable trellis wires. The vines were irrigated using aboveground drip with the drip line suspended $\mathrm{l} \mathrm{ft}$ above the soil surface. Alleyways were seeded annually in the fall with rye (Secale cereale) that was mowed in early spring during canopy development and then left to dry as soil moisture became depleted during berry development. All irrigation scheduling, canopy and nutrient management, weed removal, and pesticide application were performed by commercial vineyard employees according to their standard practices (Watson, 1999). No frost protection measures, such as wind machines or sprinklers, were used at the trial site.

The major production regions for the alternative and lead cultivars included in the trial are located in Portugal, Spain, Italy, Austria, Chile, and France (Table l). The majority of the alternative cultivars and both leading cultivars in the trial were red-skinned. All the alternative cultivars from Italy, Spain, and Chile were red-skinned. The white-skinned alternative cultivars were from Austria, France, and Portugal. The planting material was purchased from commercial nurseries as commercially certified virus-free, dormant-rooted cuttings. Most of the planting material was purchased ungrafted; however, six of the alternative cultivars had to be purchased as grafted, rooted dormant cuttings on 101-14 rootstock (Vitis riparia $\times$ Vitis rupestris) because of limited scion availability. Current industry practice in southwestern Idaho is to grow vines on their own roots rather than grafted because phylloxera (Daktulosphaira vitifoliae), a rootborne pest of wine grape, is not widespread in the region and the absence of rootstock facilitates vine retraining in the event of cold injury.

Vine phenology was characterized by recording the day of year when $50 \%$ of buds or clusters on a vine had reached stage 4 (budbreak), 23 (bloom), and 35 (veraison) of the modified E-L rating scale (Coombe, 1995). Each cultivar entry was harvested when the juice from a random sample of berries had a soluble solids concentration (SSC) of $\approx 23 \%$, a titratable acidity (TA) of $\approx 6 \mathrm{~g} \cdot \mathrm{L}^{-1}$, and a $\mathrm{pH}$ of $\approx 3.5$. SSC was used as the primary harvest indicator if TA and/ or $\mathrm{pH}$ were not at target levels. Just before harvest, two clusters were removed from each side of the interior two vines in each four-vine panel, placed into sealed plastic bags, and transported to the laboratory for determination of fruit maturity, cluster, and berry weight. All the remaining clusters were then removed from the vine and weighed to determine yield 
per vine. Dormant cuttings from the interior two vines in each panel were weighed after pruning and used to calculate the ratio of yield to pruning weight (Ravaz index), which is a standard method for estimating crop load (Howell, 2001; Vasconcelos and Castagnoli, 2000).

Each cluster sample was individually weighed. Average berry weight was calculated, in 2011 , by dividing cluster weight by the number of berries per cluster and in 2012, by measuring the weight of a 50-berry sample. The remaining berries in the eight cluster sample were hand-crushed in a sealed plastic bag, left overnight at $70{ }^{\circ} \mathrm{F}$, and then used to measure SSC, $\mathrm{pH}$, and TA the following morning using the method of Iland et al. (2004) as modified by Shellie (2006).

The incidence and severity of visible injury to aboveground perennial tissue were assessed after budbreak in 2011 and 2012 using a five-point, pretransformed rating scale, where 0 signified no visible injury and 4 signified no visible growth (Little and Hills, 1978). The hardiness of bud tissue was monitored on eight of the alternative cultivars and both leading cultivars at monthly intervals from October to March during Winters 2011-12 and 2012-13 using differential thermal analysis (DTA) to identify low-temperature exotherms (LTEs) following the method of Mills et al. (2006). Tissue subjected to DTA was excised from basal nodes three through six from a dormant cane sampled just before analysis from each replicate panel. Bud tissue was excised following the methods of Wolf and Pool (1987) and Mills et al. (2006). Twenty buds were evaluated per cultivar on each sampling date. A freezer (model T2 RC SPX; Tenney, Rochester, NY) was programmed to ramp from 0 to -40 ${ }^{\circ} \mathrm{C}$ at a rate of $4{ }^{\circ} \mathrm{C}$ per hour and LTEs were detected as voltage outputs by a Keithley Multimeter Data Acquisition System (Keithley Instruments, Cleveland, $\mathrm{OH}$ ) that recorded to a Microsoft (Redmond, WA) program ExcelLINX (Emcore Corp., Somerset, NJ). The temperature at which $50 \%$ of the sampled buds were killed was calculated from LTE data and reported as bud $\mathrm{LT}_{50}$. Because of the space limitation in the Tenney freezer, the monthly DTA was conducted over 2 consecutive days. Five cultivars were selected at random for evaluation on either the first or second day and samples were collected each month between October and March. Cane samples were collected from the field trial site on the day of analysis. Data for phenology, yield, berry composition, cold injury ratings, and cold hardiness were analyzed

Table 1. A description of the alternative and leading standard wine grape cultivars evaluated in a field trial in southwestern Idaho. The trial site was located within a commercial vineyard and was planted in 2008.

\begin{tabular}{|c|c|c|c|c|c|}
\hline \multirow{2}{*}{$\frac{\text { Cultivar (FPS clone no.) }{ }^{\mathbf{z}}}{\text { Trousseau (10) }}$} & \multirow{2}{*}{$\frac{\text { Skin color }}{\text { Red }}$} & \multirow{2}{*}{$\frac{\text { Root-stock }}{\text { Self }}$} & \multicolumn{2}{|c|}{ Principal production region ${ }^{y}$} & \multirow{2}{*}{$\frac{\text { Source }^{\mathrm{x}}}{\text { NovaVine }}$} \\
\hline & & & Portugal & Dão & \\
\hline Tinto Cão (3) & Red & Self & Portugal & Douro & NovaVine \\
\hline Graciano (1) & Red & Self & Spain & Rioja & Inland Desert \\
\hline Montepulciano (1) & Red & Self & Italy & Abruzzo & Inland Desert \\
\hline Aleatico (1) & Red & Self & Italy & Puglia & NovaVine \\
\hline Carménère (VCR 702) & Red & Self & Chile & Central Valley & NovaVine, Inland Desert \\
\hline Touriga Brasileira (1) & Red & $101-14$ & Portugal & Douro & NovaVine \\
\hline Aglianico (1) & Red & $101-14$ & Italy & Basilicata & NovaVine \\
\hline Grüner Veltliner (1) & White & Self & Austria & Weinviertel & NovaVine \\
\hline Fernão Pires (1) & White & $101-14$ & Portugal & Bairrada & NovaVine \\
\hline Verdelho (2) & White & $101-14$ & Portugal & Dão & NovaVine \\
\hline Sauvignon Blanc Musqué (27) & White & $101-14$ & France & Bordeaux & NovaVine \\
\hline
\end{tabular}

${ }^{2}$ Foundation Plant Services, University of California, Davis.

${ }^{y}$ Fegan, 2003.

${ }^{x}$ NovaVine, Santa Rosa, CA; Inland Desert Nursery, Benton City, WA.

Table 2. Weather data from the Agrimet, Nampa, ID, weather station (U.S. Department of the Interior, 2013). Accumulated growing-degree days (GDDs) calculated from daily average temperature 1 April to 31 Oct. using a base of $10{ }^{\circ} \mathrm{C}$ with no upper temperature limit.

\begin{tabular}{|c|c|c|c|c|c|c|c|}
\hline \multirow[b]{4}{*}{ Winter } & \multicolumn{4}{|c|}{ Ambient temperature } & \multirow[b]{4}{*}{ GDD $\left({ }^{\circ} \mathbf{C}\right)$} & & \\
\hline & \multicolumn{2}{|c|}{1 Nov. to 31 Mar. $\left({ }^{\circ} \mathrm{C}\right)^{\mathrm{z}}$} & \multicolumn{2}{|c|}{$\leq 0^{\circ} \mathrm{C}($ day of $\mathrm{yr})$} & & \multirow{2}{*}{\multicolumn{2}{|c|}{ Precipitation (inches) }} \\
\hline & \multirow{2}{*}{$\begin{array}{c}\text { Lowest } \\
\text { (day of year) }\end{array}$} & \multirow{2}{*}{$\begin{array}{c}\text { Avg } \\
\text { (coldest mo.) }\end{array}$} & \multirow{2}{*}{$\begin{array}{c}\text { Preceding } \\
\text { fall }\end{array}$} & \multirow{2}{*}{$\begin{array}{c}\text { Following } \\
\text { spring }\end{array}$} & & & \\
\hline & & & & & & Annual & Seasonal \\
\hline 2008-09 & $-16(352)$ & -1.2 (Dec.) & 285 & 122 & 1630 & 7.3 & 3.3 \\
\hline $2009-10$ & $-20(344)$ & -4.0 (Dec.) & 285 & 117 & 1654 & 6.9 & 4.5 \\
\hline $2010-11$ & $-13(329)$ & -1.4 (Jan.) & 313 & 127 & 1511 & 10.4 & 4.6 \\
\hline 10-year avg & -15 & -1.9 (Jan.) & 298 & 109 & 1642 & 7.6 & 4.0 \\
\hline
\end{tabular}

${ }^{20} \mathrm{~F}=\left({ }^{\circ} \mathrm{C} \times 1.8\right)+32, \mathrm{l}$ inch $=2.54 \mathrm{~cm}$. 
using a linear mixed model analysis of variance (SAS version 8.02; SAS Institute, Cary, NC). Means of fixed effect treatment levels were separated using Tukey's honestly significant difference. Bud $\mathrm{LT}_{50}$ values were graphed using SigmaPlot (version 12.0; Systat Software, San Jose, CA).

\section{Results}

ENVIRONMENTAL CONDITIONS. The minimum winter temperature was $\approx 5{ }^{\circ} \mathrm{C}$ lower than the 10 -year site average minimum temperature during Winters 2009-10 and 2012-13 (Table 2). The mean temperature of the coldest month was also lower than the 10-year site average in these study years. The occurrence of ambient temperature events $\leq 0{ }^{\circ} \mathrm{C}$ was earlier than the 10-year site average in Fall 2008 and 2009 and later than the 10-year site average in the spring of each study year except 2012. Growing season heat unit accumulation was lower than the 10-year site average in 2010 and 2011 and higher than the site average in 2012. Annual and growing season precipitation was lower than the site average in 2012.

Cold hardiness. Visible vine injury was greatest following Winter
2010-11 (Table 3). 'Tinto Cão' and 'Montepulciano' had more severe injury each year than the leading cultivars. Because of the severity of their injury, they were excluded from further evaluation in the study. After Winter 2010-11, 'Aglianico' had more severe injury than 'Merlot' and a similar amount of injury as 'Aleatico' and 'Graciano'. 'Aglianico' had more injury than 'Merlot' and a similar amount of injury as 'Cabernet Sauvignon' every year. 'Cabernet Sauvginon' had a similar amount of injury as 'Merlot' in 2010-11 and more injury than 'Merlot' in 201112 and 2012-13.

Bud cold hardiness differed between years and months and relative differences among cultivars varied by year and by month (Figs. 1 and 2 ). Bud cold hardiness increased in all cultivars from October through January and then declined in March. Differences among cultivars in bud cold hardiness were more pronounced during Winter 2011-12 than during Winter 2012-13. In October and Nov. 2011, 'Trousseau' was more cold hardy than both leading cultivars, and more cold hardy than 'Cabernet Sauvignon' in Dec.
2011. In Jan. 2013, 'Grüner Veltliner' had lower bud $\mathrm{LT}_{50}$ than all other cultivars. 'Fernão Pires' was less cold hardy than the leading cultivars in February and March of both years and 'Verdelho' and 'Touriga Brasileira' were less cold hardy than 'Cabernet Sauvignon' in March of both years.

Phenology. Budbreak, bloom, and veraison occurred at an earlier date in 2012 than in 2011 , and the number of days between budbreak and harvest were $\approx 12 \mathrm{~d}$ less in 2012 compared with 2011 (Table 4). Cultivars differed in the onset date of phenological events and the relative differences among cultivars varied by growing season. All the alternative cultivars broke bud earlier or at the same time as 'Merlot' in both years, with the exception of 'Graciano', which broke bud at a later date than any cultivar in 2012. 'Grüner Veltliner', 'Verdelho', and 'Sauvignon Gris' broke bud earlier, reached bloom and veraison earlier, and/or had fewer days between budbreak and harvest than the leading cultivars in one or both years. 'Fernão Pires', 'Sauvignon Blanc Musqué', 'Trousseau', and 'Touriga Brasileira' broke bud at the same time or earlier than

Table 3. Percent visible injury to wine grape cultivars grown in southwestern Idaho after three consecutive winters. Injury was rated in the spring using a five-point scale, where 0 indicated no injury and 4 indicated no growth. Ratings were arcsine transformed to percentages after statistical analysis.

\begin{tabular}{|c|c|c|c|c|}
\hline \multirow[b]{2}{*}{ Cultivar } & \multicolumn{3}{|c|}{ Visible vine injury in spring (\%) } & \multirow[b]{2}{*}{$3-y r$ avg } \\
\hline & Winter 2010-11 & Winter 2011-12 & Winter 2012-13 & \\
\hline Merlot & $18 \operatorname{cdef}^{z}$ & 2 def & 3 de & 6 \\
\hline Grüner Veltliner & $3 \mathrm{f}$ & $0 \mathrm{f}$ & $0 \mathrm{f}$ & 1 \\
\hline Graciano & 22 bcde & $12 \mathrm{f}$ & $1 \mathrm{f}$ & 9 \\
\hline Trousseau & $6 \mathrm{f}$ & $1 \mathrm{f}$ & $1 \mathrm{def}$ & 2 \\
\hline Aleatico & $25 \mathrm{bcd}$ & $2 \mathrm{~cd}$ & $9 \mathrm{~cd}$ & 11 \\
\hline Fernão Pires & $10 \mathrm{def}$ & $2 \mathrm{def}$ & 2 def & 4 \\
\hline Sauvignon Blanc Musqué & $6 \mathrm{ef}$ & $1 \mathrm{f}$ & $0 \mathrm{f}$ & 1 \\
\hline Carménère & $5 \mathrm{f}$ & $1 \mathrm{f}$ & $0 \mathrm{f}$ & 1 \\
\hline Verdelho & 9 def & $2 \mathrm{ef}$ & 3 def & 4 \\
\hline \multirow{2}{*}{ Annual mean } & $P$ value ${ }^{y}$ & & & \\
\hline & Injury rating & & & \\
\hline Cultivar & ** & & & \\
\hline Year & ** & & & \\
\hline Year $\times$ cultivar & $* *$ & & & \\
\hline
\end{tabular}

${ }^{\mathrm{z}}$ Mean separation by Tukey-Kramer adjusted $t$ test at $P \leq 0.05$ (lowercase letters). Any two means within a column not followed by the same letter are significantly different.

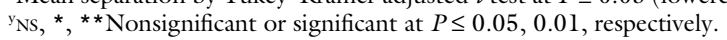




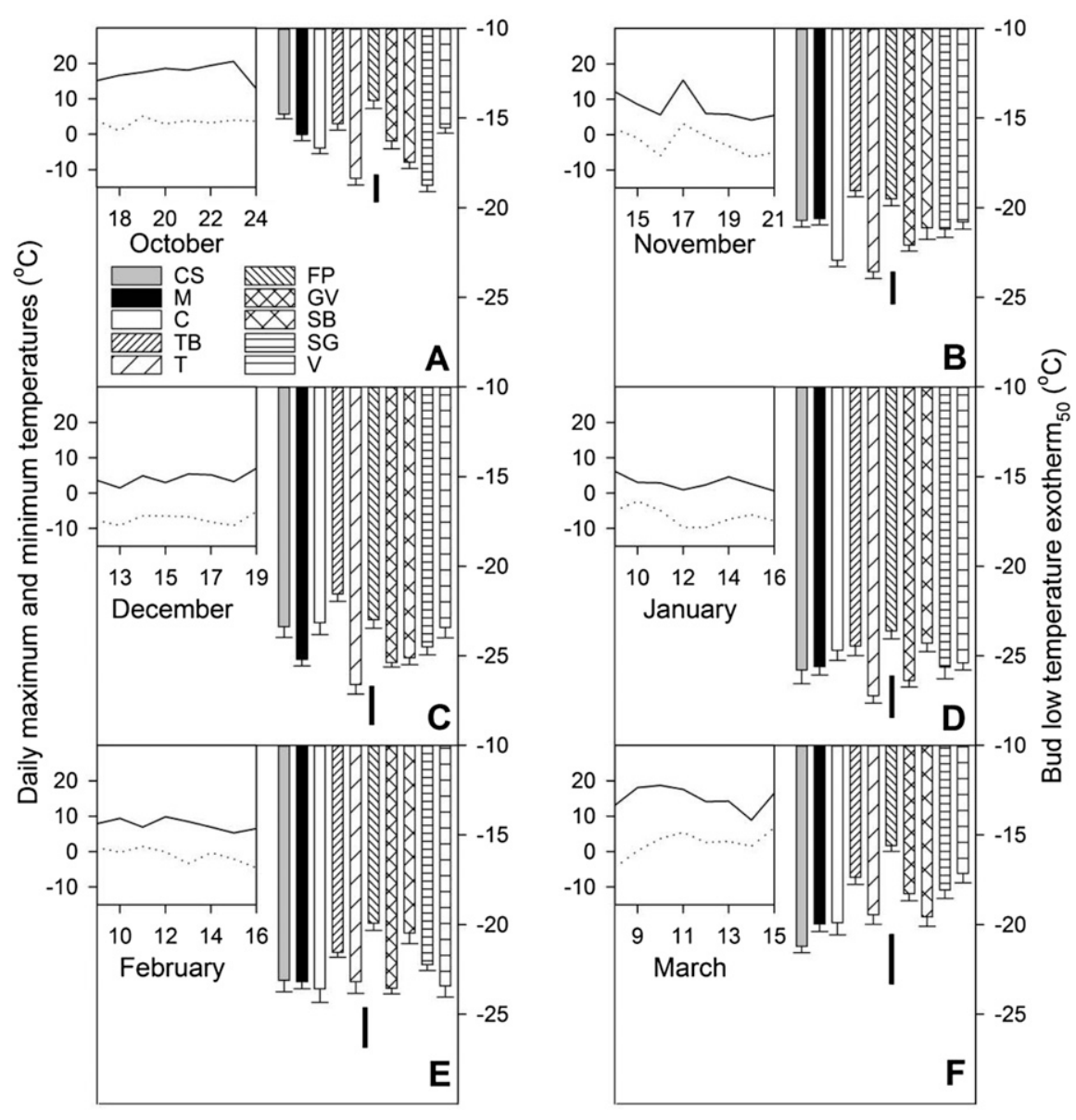

Fig. 1. Cold hardiness from Oct. 2011 to Mar. 2012 of wine grape cultivars grown in southwestern Idaho $(A-F)$. Minimum temperature of bars $( \pm S D)$ indicate the lethal temperature for $50 \%$ of buds ( $n=20$ buds) in each corresponding cultivar based upon low-temperature exotherms detected during differential thermal analysis. Thick, solid vertical line below cultivar bars indicates Tukey's honestly significant difference values $(P=0.05)$ for cultivar comparison within a particular month. Inset graphs in the upper left corner show daily maximum and minimum temperatures $\left({ }^{\circ} \mathrm{C}\right)$ for the $7 \mathrm{~d}$ preceding bud sampling. $\mathrm{CS}=$ 'Cabernet Sauvignon', $\mathbf{M}=$ 'Merlot', $\mathbf{C}=$ 'Carménère', $\mathbf{T B}=$ 'Touriga Brasileira', $\mathbf{T}$ = 'Trousseau', $\mathbf{F P}=$ 'Fernão Pires', GV = 'Grüner Veltliner', SB = 'Sauvignon Blanc Musqué', SG = 'Sauvignon Gris', V = 'Verdelho'. ${ }^{\circ} \mathrm{F}=\left({ }^{\circ} \mathrm{C} \times 1.8\right)+32$.

'Cabernet Sauvignon' each year, reached veraison earlier than 'Merlot' in both years, and had fewer days between budbreak and harvest than the leading cultivars in at least 1 year. 'Aleatico', 'Aglianico', and 'Graciano' had a greater number of days between budbreak and harvest than the leading cultivars in at least 1 year. 'Aglianico' reached veraison later than both leading cultivars each year and was harvested later than both cultivars in 2012 .

YIELD COMPONENTS AND FRUIT MATURITy. The average value for yield, pruning weight, and the Ravaz index was similar each year; however, the relative differences among cultivars for these traits varied by season (Table 5). The leading cultivars had similar yield, though 'Merlot' had a higher Ravaz index than 'Cabernet Sauvignon' in 2012. The yield of alternative cultivars was the same as one or both leading cultivars every year with the exception of 'Touriga Brasileira', whose yield was higher than the leading cultivars in 2011. 'Touriga Brasileira' also had a higher Ravaz index every year than both leading cultivars. 'Graciano' had a higher Ravaz index than the leading cultivars in 2011 and 'Grüner Veltliner' had a higher Ravaz index than leading cultivars in 2012.

Average values for berry and cluster weight were higher in 2011 than in 2012 and most cultivars had fewer clusters per vine in 2011 than in
2012 (Table 6). The leading cultivars each year had similar berry and cluster weight, a similar number of clusters per vine, and a similar number of berries per cluster. The cluster weight of alternative cultivars was the same as one or both leading cultivars every year with the exception of 'Grüner Veltliner', which had greater cluster weight than both leading cultivars in 2011. 'Carménère' had similar cluster weight as the leading cultivars, but it had fewer clusters per vine, larger berries and fewer berries per cluster than both leading cultivars in both years. Each year, 'Grüner Veltliner', 'Graciano', 'Aglianico', and 'Fernão Pires' had a greater number of berries per cluster than one or both leading cultivars. In 2012, 'Graciano' and 'Trousseau' had fewer clusters per vine, 'Trousseau' and 'Touriga Brasileira' had larger berries, and 'Sauvignon Gris' had fewer berries per cluster than the leading cultivars.

Fruit harvested in 2012 had higher SSC, lower TA, and higher $\mathrm{pH}$ than fruit harvested in 2011, although some of the differences among cultivars were inconsistent between years (Table 7). 'Merlot' had lower TA and higher $\mathrm{pH}$ than 'Cabernet Sauvignon' in both years and, in 2011, had higher SSC than 'Cabernet Sauvignon'. 'Grüner Veltliner', 'Touriga Brasileira', 'Carménère', 'Aglianico', 'Aleatico', and 'Graciano' had lower SSC than both leading cultivars in one or both years; however, only 'Aglianico', 'Aleatico', and 'Graciano' also had higher TA and lower $\mathrm{pH}$ than one or both leading cultivars. 'Touriga Brasileira' and 'Carménère' had lower SSC than the leading cultivars in one or both years, and 'Grüner Veltliner' had lower SSC than the leading cultivars in 2012. 'Aglianico' had higher TA and lower $\mathrm{pH}$ than the leading cultivars in both years and lower SSC than the leading cultivars in 2012. 'Aleatico' had higher TA and lower SSC and $\mathrm{pH}$ than the leading cultivars in 2012. 'Graciano' had lower SSC and $\mathrm{pH}$ than the leading cultivars in both years and higher TA than the leading cultivars in 2011. The SSC and TA of 'Verdelho', 'Sauvignon Blanc Musqué', 'Fernão Pires', 'Trousseau', and 'Sauvignon Gris' were similar to one or both leading cultivars; however, 'Trousseau' and 'Sauvignon Gris' had higher $\mathrm{pH}$ than the leading cultivars in one or both years. 

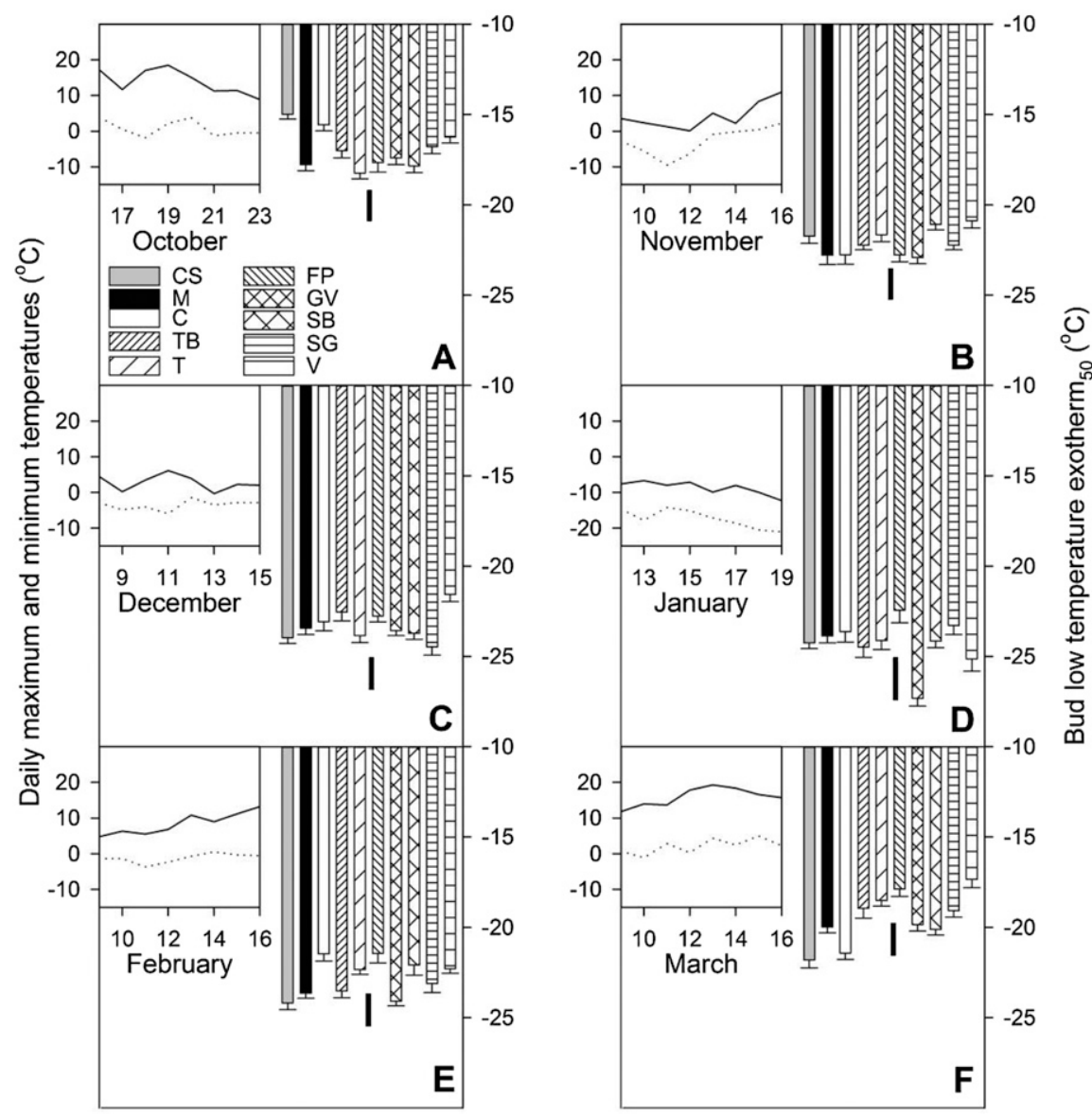

Fig. 2. Cold hardiness from Oct. 2012 to Mar. 2013 of wine grape cultivars grown in southwestern Idaho $(\mathrm{A}-\mathrm{F})$. Minimum temperature of bars $( \pm \mathrm{SD})$ indicate the lethal temperature for $50 \%$ of buds ( $n=20$ buds) in each corresponding cultivar based upon low-temperature exotherms detected during differential thermal analysis. Thick, solid vertical line below cultivar bars indicates Tukey's honestly significant difference values $(P=0.05)$ for cultivar comparison within a particular month. Inset graphs in the upper left corner show daily maximum and minimum temperatures $\left({ }^{\circ} \mathrm{C}\right)$ for the $7 \mathrm{~d}$ preceding bud sampling. $\mathrm{CS}=$ 'Cabernet Sauvignon', $\mathbf{M}=$ 'Merlot', $\mathbf{C}=$ 'Carménère', $\mathbf{T B}$ = 'Touriga Brasileira', $\mathbf{T}$ = 'Trousseau', $\mathbf{F P}=$ 'Fernão Pires', GV = 'Grüner Veltliner', SB = 'Sauvignon Blanc Musqué', SG = 'Sauvignon Gris', $\mathrm{V}=$ 'Verdelho'. ${ }^{\circ} \mathrm{F}=\left({ }^{\circ} \mathrm{C} \times 1.8\right)+32$.

\section{Discussion}

The heat unit accumulation and average growing season temperature at the field trial site in this study corresponds with the upper and lower ranges of Regions II and III in the Winkler climate classification system for grape production (Winkler et al., 1974). The leading cultivars in this study, Cabernet Sauvignon and Merlot, are considered to be well-adapted to these climatic regions (Jones et al., 2010; Winkler et al., 1974). The fewer number of days between budbreak and harvest, lower TA, and higher $\mathrm{pH}$ observed in this study in 2012 relative to 2011 was likely due to the greater heat unit accumulation in 2012. The reasons for the lower number of clusters per vine in 2011 are unclear. The late spring cold event occurred on the same day each year, yet in 2011 , the cultivars were at budbreak at the time of the event and in 2012 , the vines were $\approx 2$ weeks past budbreak. The different phenological stages of the vines at the time of the late spring cold event and the fewer number of clusters per vine in 2011 relative to 2012 pose an interesting question regarding the hardiness of floral tissue at different growth stages. Fuller and Telli (1999) reported that grapevine buds become less hardy as they transition from the first stage of bud swell to the emergence of the first green leaf tissue. Similarly, Ehlenfeldt and Arora (2008) reported a decrease in bud cold hardiness in hillside blueberry (Vaccinium constablaei) during bud opening. Unfortunately, neither of these studies compared the cold hardiness of floral tissue at budbreak relative to 2 weeks after budbreak. The possibility that floral tissue hardiness increases after budbreak warrants further evaluation. It is also possible that low cluster number in 2011 was unrelated to cold injury. The large amount of vine injury observed in Spring 2010 was likely a result of the low temperature event that occurred early in Fall 2009 and/or low midwinter temperature during Winter 2009-10. The lower berry fresh weight in 2012 relative to 2011 was likely related to low precipitation, warm temperature, and greater number of clusters per vine.

A high Ravaz index was associated with low SSC in 'Grüner Veltliner' and 'Touriga Brasileira'. 'Grüner Veltliner' and 'Touriga Brasileira' had similar dormant pruning weight and a similar number of clusters per vine as the leading cultivars; however, their large sized clusters contributed to a high Ravaz index. Reducing the number of clusters per vine in these cultivars would likely decrease their Ravaz index and facilitate the accumulation of SSC. However, a high Ravaz index was not consistently associated with low SSC in all cultivars. For example, 'Aglianico' had a higher Ravax index in 2012 than 2011 and the SSC was also higher in 2012 than 2011. Similarly, a low Ravaz index in 'Carménère' was not related to high SSC. 'Carménère' had the lowest Ravaz index in both years and was one of the cultivars with the lowest SSC. 'Carménère' also had fewer clusters per vine and its clusters contained a fewer number of larger-sized berries than the leading cultivars. The low incidence of vine injury and high bud cold hardiness of 'Carménère' suggests that its low fruitfulness was not a product of cold injury. A different clone of this cultivar would be worthy of future evaluation.

Other cultivars that differed from the leading cultivars in the Ravaz index and/or berry maturity indices were Graciano, Aglianico, and Aleatico. 'Graciano' had a low SSC and high Ravaz index in 2011, despite a greater number of days between bubreak and harvest. The high Ravaz index in 2011 was likely due to 
Table 4. Day of year (DOY) for budbreak, bloom, and veraison, and elapsed days from budbreak to harvest for wine grape cultivars grown in southwestern Idaho.

\begin{tabular}{|c|c|c|c|c|c|c|c|c|}
\hline \multirow[b]{2}{*}{ Cultivar } & \multicolumn{2}{|c|}{ Budbreak (DOY) } & \multicolumn{2}{|c|}{ Bloom (DOY) } & \multicolumn{2}{|c|}{ Veraison (DOY) } & \multicolumn{2}{|c|}{ Budbreak to harvest (d) } \\
\hline & 2011 & 2012 & 2011 & 2012 & 2011 & 2012 & 2011 & 2012 \\
\hline Merlot & $127 \mathrm{c}^{\mathrm{z}}$ & $113 \mathrm{~d}$ & $184 \mathrm{c}$ & $164 \mathrm{a}$ & $252 \mathrm{~d}$ & $237 \mathrm{~d}$ & $153 \mathrm{c}$ & $150 \mathrm{~d}$ \\
\hline Grüner Veltliner & $118 \mathrm{a}$ & $109 \mathrm{ab}$ & $181 \mathrm{a}$ & $166 \mathrm{a}$ & $241 \mathrm{ab}$ & $225 \mathrm{a}$ & $162 \mathrm{e}$ & $147 \mathrm{c}$ \\
\hline Graciano & $122 \mathrm{~b}$ & $120 \mathrm{f}$ & $184 \mathrm{c}$ & $169 \mathrm{~b}$ & $251 \mathrm{~d}$ & $239 \mathrm{~d}$ & $184 \mathrm{~h}$ & $143 \mathrm{a}$ \\
\hline Trousseau & $122 \mathrm{~b}$ & $110 \mathrm{abc}$ & $184 \mathrm{c}$ & $165 \mathrm{a}$ & $240 \mathrm{a}$ & $225 \mathrm{a}$ & $158 \mathrm{~d}$ & $145 \mathrm{~b}$ \\
\hline Aleatico & $122 \mathrm{~b}$ & $112 \mathrm{~cd}$ & $183 \mathrm{~b}$ & $180 \mathrm{c}$ & $247 \mathrm{c}$ & $230 \mathrm{~b}$ & $164 \mathrm{f}$ & $163 \mathrm{f}$ \\
\hline Fernão Pires & $120 \mathrm{ab}$ & $110 \mathrm{abc}$ & $184 \mathrm{c}$ & $164 \mathrm{a}$ & $246 \mathrm{c}$ & $230 \mathrm{~b}$ & $187 \mathrm{i}$ & $145 \mathrm{~b}$ \\
\hline $\begin{array}{l}\text { Sauvignon Blanc } \\
\text { Musqué }\end{array}$ & $120 \mathrm{ab}$ & $111 \mathrm{bc}$ & $183 \mathrm{~b}$ & $165 \mathrm{a}$ & $242 \mathrm{~b}$ & $226 a$ & $166 \mathrm{f}$ & $145 \mathrm{~b}$ \\
\hline Carménère & $127 \mathrm{c}$ & $113 \mathrm{~d}$ & $183 \mathrm{~b}$ & $163 \mathrm{a}$ & $251 \mathrm{~d}$ & $233 \mathrm{c}$ & $159 \mathrm{~d}$ & $162 \mathrm{f}$ \\
\hline
\end{tabular}

\begin{tabular}{lcccc} 
& & \multicolumn{2}{c}{$P$ value $^{\mathrm{y}}$} & \\
& Budbreak & Bloom & Veraison & $\begin{array}{c}\text { Budbreak } \\
\text { to harvest }\end{array}$ \\
Cultivar & $* *$ & $* *$ & $* *$ & $* *$ \\
Year & $* *$ & $* *$ & $* *$ & $* *$ \\
Year $\times$ cultivar & $* *$ & $* *$ & $* *$ & $* *$
\end{tabular}

${ }^{\mathrm{z}}$ Mean separation by Tukey-Kramer adjusted $t$ test at $P \leq 0.05$ (lowercase letters). Any two means within a column not followed by the same letter are significantly different. ${ }^{\mathrm{y}} \mathrm{NS},{ }^{*},{ }^{*}$ Nonsigificant or significant at $P \leq 0.05,0.01$, respectively.

a greater number of berries per cluster and greater berry weight, since pruning weight and cluster number per vine were similar in both years. In
2012, 'Graciano' had fewer clusters per vine than any other cultivar, yet it still had a lower SSC when its TA was similar to 'Cabernet Sauvignon'. In
2011 , 'Aglianico' was harvested when it had a similar SSC as 'Cabernet Sauvignon'; however, its TA was higher and $\mathrm{pH}$ was lower than both

Table 5. Average values for yield and canopy attributes of wine grape cultivars grown in southwestern Idaho over two growing seasons. Ravaz index is the ratio of yield to dormant pruning weight per vine and indicates vine crop load.

\begin{tabular}{|c|c|c|c|c|c|c|}
\hline \multirow[b]{2}{*}{ Cultivar } & \multicolumn{3}{|c|}{2011} & \multicolumn{3}{|c|}{2012} \\
\hline & Yield (kg/vine $)^{\mathrm{z}}$ & Pruning wt (kg) & Ravaz index & Yield (kg/vine) & Pruning wt (kg) & Ravaz index \\
\hline Merlot & $6.3 b^{y}$ & $1.1 \mathrm{ab}$ & $5.7 \mathrm{~cd}$ & $8.0 \mathrm{ab}$ & $1.1 \mathrm{abc}$ & $8.0 \mathrm{bc}$ \\
\hline Cabernet Sauvignon & $5.5 \mathrm{c}$ & NA & NA & $5.8 \mathrm{bc}$ & $1.3 \mathrm{a}$ & $4.8 \mathrm{ef}$ \\
\hline Grüner Veltliner & $8.8 \mathrm{ab}$ & $1.0 \mathrm{ab}$ & $11.3 \mathrm{abc}$ & $10.7 \mathrm{a}$ & $1.0 \mathrm{abc}$ & $10.8 \mathrm{a}$ \\
\hline Graciano & $6.8 \mathrm{abc}$ & $0.6 \mathrm{~b}$ & $13.2 \mathrm{ab}$ & $5.1 \mathrm{bc}$ & $0.7 \mathrm{bc}$ & $7.9 \mathrm{bcd}$ \\
\hline Trousseau & $6.9 \mathrm{abc}$ & $1.0 \mathrm{ab}$ & $7.7 \mathrm{bcd}$ & $5.7 \mathrm{bc}$ & $1.1 \mathrm{ab}$ & $5.2 \mathrm{e}$ \\
\hline Aglianico & $7.8 \mathrm{abc}$ & $0.7 \mathrm{ab}$ & $10.5 \mathrm{abc}$ & $7.6 \mathrm{abc}$ & $0.7 \mathrm{bc}$ & $11.2 \mathrm{a}$ \\
\hline Touriga Brasileira & $10.3 \mathrm{a}$ & $0.7 \mathrm{ab}$ & $14.5 \mathrm{a}$ & $7.4 \mathrm{abc}$ & $0.6 \mathrm{c}$ & $12.4 \mathrm{a}$ \\
\hline Aleatico & $7.2 \mathrm{abc}$ & $0.9 \mathrm{ab}$ & $9.1 \mathrm{abc}$ & $6.27 \mathrm{abc}$ & $1.18 \mathrm{a}$ & $5.5 \mathrm{de}$ \\
\hline Fernão Pires & $6.9 \mathrm{abc}$ & $0.7 \mathrm{ab}$ & $8.3 \mathrm{bcd}$ & $7.12 \mathrm{abc}$ & $0.88 \mathrm{abc}$ & $8.1 \mathrm{bc}$ \\
\hline $\begin{array}{l}\text { Sauvignon Blanc } \\
\text { Musqué }\end{array}$ & 7.9 abc & $1.3 \mathrm{ab}$ & $6.7 \mathrm{~cd}$ & $6.93 \mathrm{abc}$ & $1.05 \mathrm{abc}$ & $6.7 \mathrm{cde}$ \\
\hline Carménère & $3.4 \mathrm{c}$ & $1.3 \mathrm{a}$ & $2.3 \mathrm{~d}$ & $2.83 \mathrm{c}$ & $1.18 \mathrm{a}$ & $2.6 \mathrm{f}$ \\
\hline Verdelho & $7.0 \mathrm{abc}$ & $1.1 \mathrm{ab}$ & $6.5 \mathrm{~cd}$ & $8.22 \mathrm{ab}$ & $0.87 \mathrm{abc}$ & $9.6 \mathrm{ab}$ \\
\hline Sauvignon Gris & $6.3 \mathrm{abc}$ & $1.3 \mathrm{ab}$ & $5.3 \mathrm{~cd}$ & $5.36 \mathrm{bc}$ & $1.06 \mathrm{abc}$ & $5.4 \mathrm{e}$ \\
\hline \multirow[t]{3}{*}{ Annual mean } & 7.0 & 1.0 & 8.0 & 6.7 & 1.0 & 7.3 \\
\hline & & $P$ value $^{\mathrm{x}}$ & & & & \\
\hline & Yield & Pruning wt & Ravaz index & & & \\
\hline Cultivar & $* *$ & $* *$ & ** & & & \\
\hline Year & NS & NS & NS & & & \\
\hline Year $\times$ cultivar & ** & ** & * & & & \\
\hline
\end{tabular}

${ }^{\mathrm{z}} \mathrm{l} \mathrm{kg}=2.2046 \mathrm{lb}$.

${ }^{\mathrm{y}}$ Mean separation by Tukey-Kramer adjusted $t$ test at $P \leq 0.05$ (lowercase letters). Any two means within a column not followed by the same letter are significantly different. ${ }^{\mathrm{x}} \mathrm{NS},{ }^{*},{ }^{*}$ Nonsignificant or significant at $P \leq 0.05,0.01$, respectively. 
Table 6. Average values for cluster and berry attributes of wine grape cultivars grown in southwestern Idaho over two growing seasons.

\begin{tabular}{|c|c|c|c|c|c|c|c|c|}
\hline \multirow[b]{2}{*}{ Cultivar } & \multicolumn{4}{|c|}{2011} & \multicolumn{4}{|c|}{2012} \\
\hline & $\begin{array}{c}\text { Berry } \\
\text { wt }(g)^{z}\end{array}$ & $\begin{array}{l}\text { Cluster } \\
\text { wt (g) }\end{array}$ & $\begin{array}{l}\text { Clusters per } \\
\text { vine (no.) }\end{array}$ & $\begin{array}{l}\text { Berries per } \\
\text { cluster (no.) }\end{array}$ & $\begin{array}{c}\text { Berry } \\
\text { wt }(g)\end{array}$ & $\begin{array}{l}\text { Cluster } \\
\text { wt (g) }\end{array}$ & $\begin{array}{l}\text { Clusters per } \\
\text { vine (no.) }\end{array}$ & $\begin{array}{l}\text { Berries per } \\
\text { cluster (no.) }\end{array}$ \\
\hline Cabernet Sauvignon & $1.07 \mathrm{~d}$ & $155.54 \mathrm{~b}$ & $38 \mathrm{abc}$ & $144 \mathrm{~cd}$ & $0.79 \mathrm{e}$ & $128.81 \mathrm{bcd}$ & $46 \mathrm{ab}$ & $161 \mathrm{cde}$ \\
\hline Grüner Veltliner & $1.26 \mathrm{bcd}$ & $292.47 \mathrm{a}$ & $31 \mathrm{bcd}$ & 231 a & $1.07 \mathrm{~cd}$ & $210.29 \mathrm{a}$ & 52 a & $201 \mathrm{abc}$ \\
\hline Graciano & $1.14 \mathrm{~cd}$ & $236.90 \mathrm{ab}$ & $29 \mathrm{~cd}$ & $221 \mathrm{a}$ & $0.98 \mathrm{cde}$ & $204.24 \mathrm{ab}$ & $26 \mathrm{e}$ & $208 \mathrm{ab}$ \\
\hline Touriga Brasileira & $1.58 \mathrm{ab}$ & $221.47 \mathrm{ab}$ & $50 \mathrm{a}$ & $150 \mathrm{~cd}$ & $1.09 \mathrm{c}$ & $164.23 \mathrm{abcd}$ & $47 \mathrm{ab}$ & 147 def \\
\hline Aleatico & $1.29 \mathrm{bcd}$ & $203.51 \mathrm{ab}$ & $37 \mathrm{abc}$ & $160 \mathrm{bcd}$ & $1.04 \mathrm{~cd}$ & $124.93 \mathrm{bcd}$ & $50 \mathrm{ab}$ & $126 \mathrm{efg}$ \\
\hline Fernão Pires & $1.15 \mathrm{~cd}$ & $198.68 \mathrm{ab}$ & $35 \mathrm{bc}$ & $186 \mathrm{abc}$ & $0.78 \mathrm{e}$ & $172.60 \mathrm{abcd}$ & 40 abcd & $227 \mathrm{a}$ \\
\hline $\begin{array}{l}\text { Sauvignon Blanc } \\
\text { Musqué }\end{array}$ & $1.16 \mathrm{~cd}$ & $181.55 \mathrm{~b}$ & $43 \mathrm{abc}$ & $155 \mathrm{bcd}$ & $1.06 \mathrm{~cd}$ & $159.39 \mathrm{abcd}$ & $42 \mathrm{abc}$ & $150 \mathrm{def}$ \\
\hline Carménère & $1.67 \mathrm{a}$ & $173.57 \mathrm{~b}$ & $18 \mathrm{~d}$ & $103 \mathrm{e}$ & $1.21 \mathrm{ab}$ & $102.10 \mathrm{~d}$ & $26 \mathrm{~d}$ & $88 \mathrm{~g}$ \\
\hline \multirow{2}{*}{ Annual mean } & \multicolumn{4}{|c|}{$P$ value $^{\mathrm{x}}$} & & & & \\
\hline & Berry wt & Cluster wt & $\begin{array}{l}\text { Clusters } \\
\text { per vine }\end{array}$ & $\begin{array}{c}\text { Berries } \\
\text { per cluster }\end{array}$ & & & & \\
\hline Year & ** & ** & $* *$ & NS & & & & \\
\hline Cultivar & ** & ** & ** & ** & & & & \\
\hline Year $\times$ cultivar & NS & ** & NS & NS & & & & \\
\hline
\end{tabular}

${ }^{\mathrm{z}} \mathrm{lg}=0.0353 \mathrm{oz}$.

y Mean separation by Tukey-Kramer adjusted $t$ test at $P \leq 0.05$ (lowercase letters). Any two means within a column not followed by the same letter are significantly different. ${ }^{\mathrm{x}} \mathrm{N},{ }^{*},{ }^{*}$ Nonsignificant or significant at $P \leq 0.05$ or 0.01 , respectively.

leading cultivars. In 2012, 'Aglianico' was harvested $14 \mathrm{~d}$ later relative to 2011, yet it still had lower SSC, higher TA, and lower $\mathrm{pH}$ than the leading cultivars. 'Aleatico' had a similar Ravax index as the leading cultivars, but it had a higher TA than the leading cultivars in both years and lower SSC than both cultivars in the

Table 7. Berry maturity indices at harvest [ soluble solids concentration (SSC), titratable acidity (TA), and pH] for wine grape cultivars grown in southwestern Idaho.

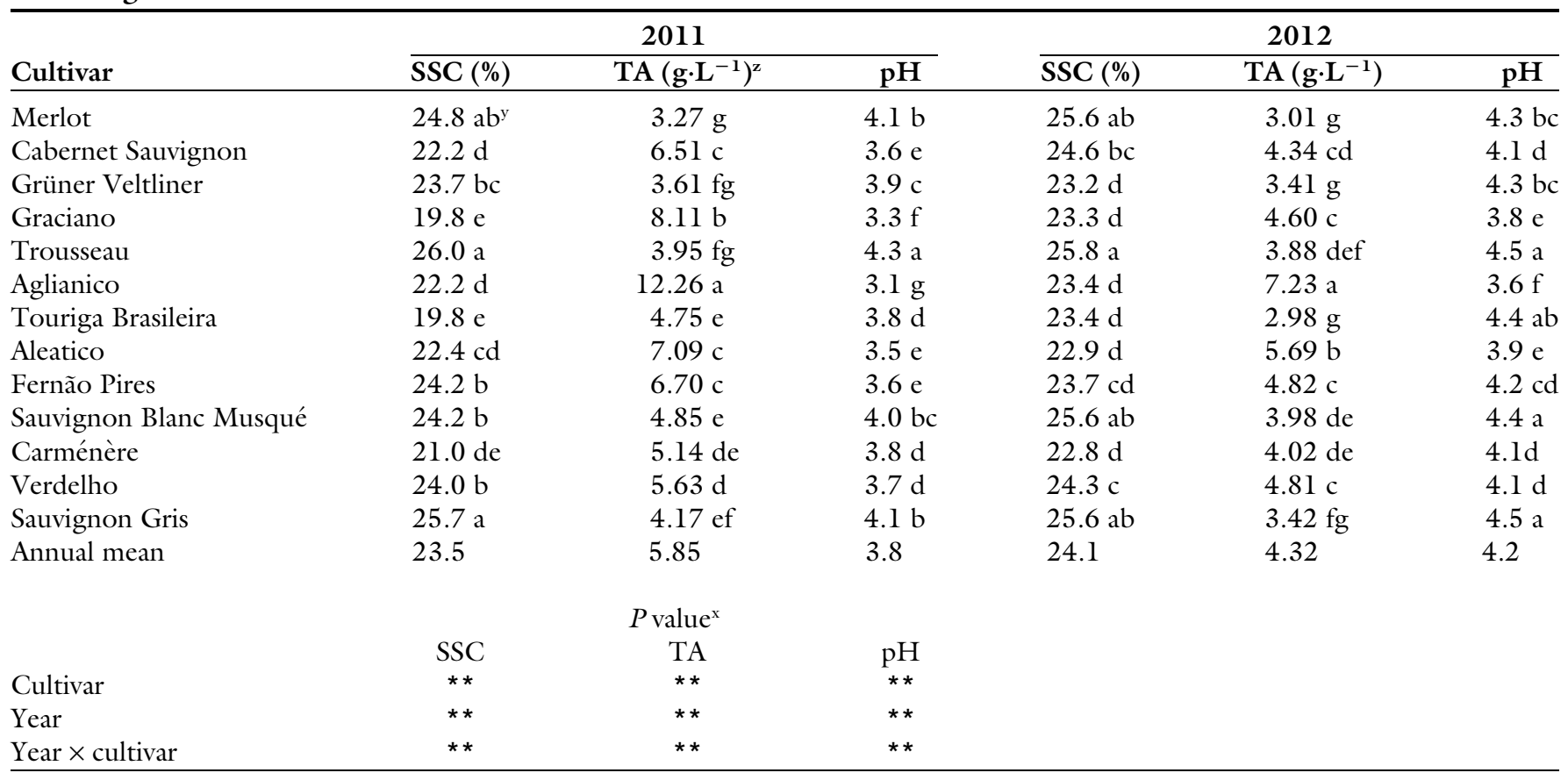

${ }^{2} 1 \mathrm{~g} \cdot \mathrm{L}^{-1}=0.1 \%$.

${ }^{y}$ Mean separation by Tukey-Kramer adjusted $t$ test at $P \leq 0.05$ (lowercase letters). Any two means within a column not followed by the same letter are significantly different. ${ }^{\mathrm{x}} \mathrm{NS},{ }^{*},{ }^{* *}$ Nonsignificant or significant at $P \leq 0.05,0.01$, respectively. 
warmest growing season. The high incidence of vine injury and imbalance of fruit maturity indices in 'Graciano', 'Aglianico', and 'Aleatico' indicate that these cultivars are cold sensitive and better suited to a longer, warmer growing season than the site in this study.

The differences among cultivars in cold tolerance enabled us to identify alternative cultivars with low production potential for this climatic region. 'Montepulciano' and 'Tinto Cão' were particularly sensitive to winter cold injury, and 'Aleatico', 'Aglianico', and 'Graciano' were cold sensitive and late maturing. The mean temperature of the coldest month in the principal regions where these cultivars are grown is warmer than the winter temperatures at the site in this study. However, our results demonstrate that the temperature of the current major production region is not necessarily predictive for cold tolerance. For example, 'Trousseau', 'Verdelho', and 'Sauvignon Gris' exhibited good cold tolerance even though they are principally produced in regions without winter cold. There is a wealth of information showing differences in cold tolerance among leading cultivars of wine grape; however, we could not find any published data on the cold hardiness of the alternative cultivars evaluated in this study. The seasonal pattern of cold hardiness we observed in this study was similar to what others have reported for leading wine grape cultivars (Fennell, 2004; Ferguson et al., 2011; Hamman et al., 1996; Mills et al., 2006).

The onset of cold acclimation and deacclimation during dormancy may be as important a determinant to winter survival as midwinter maximum cold hardiness (Kalberer et al., 2006). Relatively little is known about how cold hardiness is maintained and/ or reacquired in late winter and spring, and differences in hardiness are likely a combination of genetic factors that influence sensitivity to environmental cues (Wample et al., 2000). The amount of variability we observed among alternative cultivars in bud cold hardiness during months of acclimation and deacclimation and midwinter was similar to what has been reported for leading wine grape cultivars (Andrews et al., 1984; Ferguson et al., 2011; Wolf and Cook, 1992). Cultivars slow to acclimate in the fall and quick to deacclimate in the spring, such as 'Fernão Pires' and 'Touriga Brasileira', may be best suited for production sites with low risk of early or late-season cold events. Cultivars quick to acclimate and deacclimate and break bud in the spring, such as 'Verdelho' and 'Gruner Veltliner', may be best suited for production sites more prone to autumn than late spring cold events.

\section{Conclusion}

The alternative cultivars evaluated in this study exhibited variability for the onset of phenological events, cold tolerance, and cluster architecture. The cultivars Montepulciano and Tinto Cão were most sensitive to cold injury and therefore less suitable for production where growing season is delimited by low temperature. The late fruit maturity exhibited by 'Graciano', 'Aglianico', and 'Aleatico' suggests that these cultivars are best suited for sites with higher heat unit accumulation and/or a longer growing season than the trial site in this study. The delay in onset of bud cold hardiness in the fall and early deacclimation in the spring of 'Fernão Pires' and 'Touriga Brasileira' suggests that these cultivars are best suited to sites not prone to early autumn or late spring cold events. The early cold acclimation of 'Grüner Veltliner', 'Sauvignon Gris', and 'Trousseau' suggests good suitability for sites prone to early autumn cold events. 'Grüner Veltliner' broke bud early and had greater yield, cluster weight, and number of berries per cluster than both leading cultivars. 'Trousseau' ripened early and had greater berry and cluster weight and similar yield as both leading cultivars. 'Sauvignon Gris' had similar yield, fewer berries per cluster, and greater berry weight than both leading cultivars. The variability among cultivars observed in this study can be used to guide cultivar selection for growing sites differing in heat unit accumulation, frost susceptibility, and low winter temperatures.

\section{Literature cited}

Andrews, P.K., C.R. Sandidge, and T.K. Toyama. 1984. Deep supercooling of dormant and deacclimating Vitis buds. Amer. J. Enol. Viticult. 35:175-177.

Bierle, K., D. Holley, and G. Black. 2008. The economic impact of the wine industry on Idaho's Economy. Boise State Univ., Ctr. Business Econ. Res., Boise, ID.

Coombe, B.G. 1995. Adoption of a system for identifying grapevine growth stages. Aust. J. Grape Wine Res. 1:100-110.

Ehlenfeldt, M.K. and R. Arora. 2008. Cold tolerance of blueberry genotypes throughout the dormant period from acclimation to deacclimation. HortScience 43:1970-1974.

Fallahi, E., B. Shafii, B. Fallahi, J.C. Stark, and A.L. Ebgel. 2004. Yield, quality attributes, and degree day requirements of various wine grapes under the climatic conditions of Intermountain West region. J. Amer. Pomol. Soc. 58:156-652.

Fegan, P.W. 2003. The vineyard handbook: Appellations, maps and statistics. Chicago Wine School, Chicago, IL.

Fennell, A. 2004. Freezing tolerance and injury in grapevines. J. Crop Improv. 10:201-235.

Ferguson, J.C., J.M. Tarara, L.J. Mills, G.G. Grove, and M. Keller. 2011. Dynamic thermal time model of cold hardiness for dormant grapevine buds. Ann. Bot. (Lond.) 107:389-396.

Foltz, J.C., S. Woodall, P.R. Wandschneider, and R.G. Taylor. 2007. The contribution of the grape and wine industry to Idaho's economy: Agribusiness and tourism impacts. J. Agribusiness 25:77-91.

Fuller, M.P. and G. Telli. 1999. An investigation of the frost hardiness of grapevine (Vitis vinifera) during bud break. Ann. Appl. Biol. 135:589-595.

Gillerman, V.S., D. Wilkins, K.C. Shellie, and R. Bitner. 2006. Geology and wine 11: Terroir of the western Snake River Plain, Idaho. GeoScience Can. 33:37-48.

Hamman, R.A. Jr., I.E. Dami, T.M. Walsh, and C. Stushnoff. 1996. Seasonal carbohydrate changes and cold hardiness of Chardonnay and Riesling grapevines. Amer. J. Enol. Viticult. 7:31-36.

Howell, G.S. 2001. Sustainable grape productivity and the growth-yield relationship: A review. Amer. J. Enol. Viticult. 52:165-174.

Iland, P.N., N. Bruer, G. Edwards, S. Weeks, and E. Wilkes. 2004. Chemical analysis of grapes and wine: Techniques and concepts. Patrick Iland, Campbelltown, Australia.

Jones, G.V., A.A. Duff, A. Hall, and J.W. Myers. 2010. Spatial analysis of climate in wine grape growing regions in the western United States. Amer. J. Enol. Viticult. 61:313-326.

Kalberer, S.R., M. Wisniewski, and R. Arora. 2006. Deacclimation and reacclimation of 
cold-hardy plants: Current understanding and emerging concepts. Plant Sci. $171: 3-16$.

Little, T.M. and F.J. Hills. 1978. Agricultural experimentation design and analysis. Wiley, New York, NY.

Mills, L.J., J.C. Ferguson, and M. Keller. 2006. Cold-Hardiness evaluation of grapevine buds and cane tissues. Amer. J. Enol. Viticult. 57:194-200.

Shellie, K.C. 2006. Vine and berry response of Merlot (Vitis vinifera L.) to differential water stress. Amer. J. Enol. Viticult. 57:514-518.

Shellie, K.C. 2007. Viticultural performance of red and white wine grape cultivars in southwestern Idaho. HortTechnology 17:595-603.

U.S. Department of Agriculture. 1972. Soil survey of Canyon Area, Idaho. U.S. Govt. Printing Office, Washington, DC.
U.S. Department of Agriculture. 2007. Census of agriculture. 28 Dec. 2012. <http:// www.agcensus.usda.gov/Publications / 2007/Full_Report/Volume_1,_Chapter_ 2_US_State_Level/st99_2_032_032.pdf $>$.

U.S. Department of Agriculture. 2013. Web soil survey. 21 Nov. 2013. <http:// websoilsurvey.nrcs.usda.gov/app/ WebSoilSurvey.aspx $>$.

U.S. Department of Commerce. 2011. U.S. wine industry: 2011. 22 Jan. 2013. <http://www.ita.doc.gov/td/ocg/ wine2011.pdf>.

U.S. Department of the Interior. 2013. Agrimet: The Pacific Northwest cooperative agricultural network. 3 Jan. 2013. <http://www.usbr.gov/pn/agrimet/ wxdata.html>.

Vasconcelos, M.C. and S. Castagnoli. 2000. Leaf canopy structure and vine performance. Amer. J. Enol. Viticult. 51:390-396.
Wample, R.L., S. Hartley, and L. Mills. 2000. Dynamics of grapevine cold hardiness. Amer. J. Enol. Viticult. 51:81-93.

Watson, J. 1999. Washington viticulture: The basics, p. 13-20. In: J. Watson (ed.). Growing grapes in eastern Washington. Good Fruit Grower, Yakima, WA.

Winkler, A.J., J.A. Cook, W.M. Kliewer, and L.A. Lider. 1974. Climate and soils, p. 61-71. In: A.J. Winkler, J.A. Cook, W.M. Kliewer, and L.A. Lider (eds.). General viticulture. 2nd ed. University of California Press, Berkley, CA.

Wolf, T.K. and M.K. Cook. 1992. Seasonal deacclimation patterns of three grape cultivars at constant, warm temperature. Amer. J. Enol. Viticult. 43:171179.

Wolf, T.K. and R.M. Pool. 1987. Factors affecting exotherm detection in differential thermal analysis of grapevine dormant buds. J. Amer. Soc. Hort. Sci. 112:520-552. 